\title{
Effect of dried earth worm (Aporrectodea caliginosa) as replacement of fish meal on growth and survival rate of the freshwater prawn, Macrobrachioum rosenbergii (DE MAN 1879) larvae.
}

\author{
Madlen M. Habashy \\ National Institute of Oceanography and Fisheries, El-Qanater El-Khayria, Egypt
}

\begin{abstract}
An experiment was conducted to evaluate the potential of earthworm powder in replacement of the high cost fish meal for feeding the freshwater prawn, Macrobrachium rosenbergii. Triplicate groups of prawns were fed on control diet (fish meal based protein) or experimental diets in which earthworm meal was used to replace fish meal as animal protein source at various inclusion levels namely $0 \%$ (control), 25, 50, 75 and 100\%. The diets were coded EM1 (control) to EM5. The highest growth performance in term of length, weight and SGR were observed in prawn fed on EM2. The lowest and best feed conversion ratio, 1.1 was recorded with diet containing 25\% earthworm meal (EM2). Highest survival (93.5\%) was observed within the prawn group fed on the same diet. Biochemical composition of prawn carcasses showed no significant differences among different diets, while the higher level of protein was found in prawn fed on EM2. Results revealed that $25 \%$ earthworm meal is recommended in the diet of $M$. rosenbergii as replacement of fish meal.
\end{abstract}

Keywords: Earthworm, feeding, Macrobrachium rosenbergii, proximate composition.

\section{INTRODUCTION}

Aquaculture is the growing of aquatic plants or animals for all or part of their life cycles. Primarily, its role is to produce food for human consumption, but it also has other purposes such as ornamental uses and as an aquarium. According to FAO (2010) the total aquaculture production of the world in 2009 reached 55.1 million tonnes, including 35 million tonnes from inland fisheries. The demand is expected to increase, and so aquaculture will become increasingly importance in the future. The practice of aquaculture in inland fisheries is by many methods, but most effort is directed to intensive systems. The importance of fish meal as feed ingredient in fish and shrimp production is quite enormous. It is a feed ingredient with very high nutrient density and high digestibility. Among the animal protein sources fish meal is particularly suited to meet the nutrient requirements of animals (Karimi 2006). The high cost and scarcity of fish meal in formulated feeds has led to the use of other alternative protein sources such as Toad meal (Annune 1990), Tadpole meal(Ayinla et al. 1994; Sogbesan et al. 2007), fermented fish silage (Fagbenro and Jauncey 1995), Maggot meal (Ugwumba et al., 2001; Sogbesan et al., 2005), poultry dung meal (Fasakin et al., 2000) and Garden snail meal (Sogbesan et al. 2006 a \& b), earthworm meal (Sogbesan et al., 2007; u Dinh Ton et al., 2009)).

Freshwater prawns are members of phylum Arthopoda. They are decapod crustaceans related to crabs and marine shrimp, but in their native land of Malaysia and Southeast Asia, Macrobrachium rosenbergii has evolved to survive in the brackish water of the estuaries and the freshwater rivers. It feeds on any available 
food, including plankton, insects, fish, benthic invertebrates (annelids), tadpoles, snails, Tubifex worms, clams and detritus (Spotts, 1981) in the wild. The optimum protein requirements for the larvae stage as reported by Rangacharyulu (1999) ranged from 30 to $45 \%$ which is the most expensive nutrient in feed formulation.

Earthworm culture is developing in many regions nowadays. Earthworm can be produced by simple methods from many kinds of organic materials. Earthworms have high protein content with a well-balanced array of essential amino acids. For this reason, earthworm have been shown to be an important feed resource for raising prawn M. dayanum (Langer et al., 2011), fish (Yaqub, 1997; Sogbesan et al. 2007; Loan et al. 2009) and frogs (Latsamy and Preston, 2007). Products of earthworm can be used as an alternative protein source for many cultured animals such as pig, poultry, fish and shrimp. However, the utilization of earthworm powder as protein source in aqua feeds is poorly studied.

The present study was conducted to evaluate the potential of earthworm powder in replacement of fish meal for feeding the freshwater prawn, $M$. rosenbergii.

\section{MATERIALS AND METHODS}

\section{Site of experiment}

The experiment was conducted from June 2010 to August 2010 in Invertebrate Laboratory, Fish Research Station, National Institute of Oceanography and Fisheries(NIOF), El-Qanater El-Khayria, Egypt.

Classification of the used earth worm

Kingdom: Metazoa

Phylum: Annelida

Class: Oligochaeta

Order: Haplotaxida

Family: Lumbricidae

Suborder: Lumbricina

Genus: Aporrectodea

Species: Aporrectodea caliginosa

Collection of earth worm

A huge numbers of earth worms were collected from moist loamy-sandy soil at El-Qanater El-Khayria, where this species is available and easily to be collected. The harvested worms were thoroughly rinsed in water and kept in a bowl for $30 \mathrm{~min}$ to evacuate the residual undigested contents in their guts (Akpodiete and Okagbare, 1999). Then earth worms were weighed and dried in an oven at $80^{\circ} \mathrm{C}$ fro $3 \mathrm{~h}$. After drying, the worms re-weighed, then milled with hammer milling machine into powdered form, packed as dried earthworm meal in an airtight plastic bowel and stored at $2-20^{\circ} \mathrm{C}$ till when needed.

\section{Feeding experiments and diets preparation}

A completely randomized design was used, with each treatment. Five experimental diets which were isonitrogenous at about $42.5 \%$ crude protein were formulated using the method of Falayi (2003). In the diets earthworm meal was used to replace fish meal as animal protein source at various inclusion levels namely $0 \%$ (control), 25, 50, 75 and 100\%. The diets were coded EM1 (control) to EM5. The percentage composition of the ingredients and production costs in the diets is shown in Table (1).

After formulation, maize, fish meal, rice bran, soybean, salt and corn oil, blood meal, bone meal, and vitamin premix were purchased from local market and were 
measured with earthworm powder using electric sensitive weighing balance (Model MR-220), milled into fine particles using hammer machine and mixed thoroughly in a bowl for $30 \mathrm{~min}$. to ensure homogeneity of the ingredients. Starch was prepared with hot water into past and mixed with the other ingredients as binder.

Table 1: Composition ( $\%$ on dry matter basis) of the experimental diets.

\begin{tabular}{lccccc}
\hline \multicolumn{7}{c}{ Experimental Diets } & & & \\
\hline & EM1(Control) & EM2 & EM3 & EM4 & EM5 \\
\hline Fish meal & 30.00 & 22.50 & 15.00 & 7.50 & 0.00 \\
\hline Earthworm meal & 0.00 & 7.50 & 15.00 & 22.50 & 30.00 \\
\hline Yellow Maize & 28.70 & 26.90 & 26.10 & 23.50 & 18.70 \\
\hline Rice bran & 11.70 & 12.60 & 13.40 & 14.20 & 16.20 \\
\hline Soya bean meal & 12.60 & 13.50 & 13.50 & 13.50 & 18.10 \\
\hline Blood meal & 10.00 & 10.00 & 10.00 & 10.00 & 10.00 \\
\hline Vitamin Mineral premix* & 2.00 & 2.00 & 2.00 & 2.00 & 2.00 \\
\hline Corn oil & 2.00 & 2.00 & 2.00 & 2.00 & 2.00 \\
\hline Common salt & 0.50 & 0.50 & 0.50 & 0.50 & 0.50 \\
\hline Bone meal & 1.00 & 1.00 & 1.00 & 1.00 & 1.00 \\
\hline Starch binder & 1.50 & 1.50 & 1.50 & 1.50 & 1.50 \\
\hline Total & 100.0 & 100.0 & 100.0 & 100.0 & 100.0 \\
\hline Calculated crude protein $(\%)$ & 42.50 & 1900 & 42.50 & 42.50 & 42.50 \\
\hline Calculated gross energy $(\mathrm{KJ} / 100 \mathrm{~g})$ & 1900 & 42.50 & 1900 & 1900 & 1900 \\
\hline
\end{tabular}

*Vitamins and Minerals: Vitamin A- 10,000,000 I.U.; D3-2,000,000 I.U.; E- 23,000mg; K3- 2,000 mg; $\mathrm{B}_{1}-3000 \mathrm{mg} ; \mathrm{B}_{2}-6000 \mathrm{mg}$; Nacin- 50,000 mg; Calcium Pathonate- 10,000 mg; $\mathrm{B}_{6}-5000 \mathrm{mg} ; \mathrm{B}_{12}-25.0$ mg; Folic acid 1,000 mg; Biotin- 50 mg; Choline Chloride- 400,000 mg; Manganese-120,000 mg; Iron100,000mg; Copper-8,500 mg; Iodine-1500 mg; Cobalt-300 mg; Selenium-120 mg; Antioxidant120,000 mg; EM= Earthworm Meal.

The dough was pelleted wet using hand pelleting machine (Kitchen hand Cranker oelletizer). The pelleted product was transferred in a flat trays and sundried to constant weight after which the feeds were crushed into crumbs with pestle and mortar (for easy ingestion by the prawn larvae). They were packed in jute bags, labeled and stored at $-20^{\circ} \mathrm{C}$. The proximate composition of earth worm, fish meal and experimental diets are shown in Table (2).

Table 2: Proximate composition of earthworm meal, fish meal and experimental diets (g/100g dry matter) used for experiment

\begin{tabular}{|c|c|c|c|c|c|c|c|}
\hline Parameters & Fish meal & Earthworm meal & $\begin{array}{l}\text { EM1 } \\
\text { (control) }\end{array}$ & EM2 & EM3 & EM4 & EM5 \\
\hline Dry matter (\%) & $90.20^{\mathrm{a}}$ & $91.43^{\mathrm{a}}$ & $84.27^{\mathrm{b}}$ & $84.39^{b}$ & $84.51^{b}$ & $85.0^{b}$ & $84.9^{b}$ \\
\hline Crude protein $(\%)$ & $71.48^{\mathrm{a}}$ & $64.04^{\mathrm{b}}$ & $44.5^{\mathrm{c}}$ & $43.45^{\mathrm{c}}$ & $43.30^{\mathrm{c}}$ & $42.99^{c}$ & $42.98^{\mathrm{c}}$ \\
\hline Crude lipid (\%) & $7.98^{\mathrm{a}}$ & $5.92^{\mathrm{a}}$ & $10.61^{\mathrm{b}}$ & $10.40^{\mathrm{b}}$ & $10.68^{b}$ & $11.1^{\mathrm{b}}$ & $11.2^{\mathrm{b}}$ \\
\hline $\operatorname{Ash}(\%)$ & $7.35^{\mathrm{b}}$ & $8.88^{\mathrm{a}}$ & $8.40^{\mathrm{a}}$ & $7.66^{\mathrm{a}}$ & $6.88^{\mathrm{a}}$ & $6.14^{\mathrm{c}}$ & $4.05^{\mathrm{c}}$ \\
\hline Nitrogen free extract (\%) & $3.15^{\mathrm{c}}$ & $11.72^{\mathrm{b}}$ & $18.31^{\mathrm{a}}$ & $19.41^{\mathrm{a}}$ & $20.1^{\mathrm{a}}$ & $20.43^{\mathrm{a}}$ & $20.64^{\mathrm{a}}$ \\
\hline $\operatorname{Sodium}(g / 100 g)$ & $0.92^{\mathrm{a}}$ & $0.41^{\mathrm{b}}$ & $0.54^{\mathrm{b}}$ & $0.50^{\mathrm{b}}$ & $0.43^{b}$ & $0.40^{\mathrm{b}}$ & $0.39^{\mathrm{b}}$ \\
\hline Potassium (g) & $0.93^{\mathrm{a}}$ & $0.60^{\mathrm{b}}$ & $0.72^{\mathrm{b}}$ & $0.71^{b}$ & $0.71^{\mathrm{b}}$ & $0.67^{\mathrm{b}}$ & $0.73^{b}$ \\
\hline Gross energy $(\mathrm{KJ} / 100 \mathrm{~g})$ & $2075^{\mathrm{a}}$ & $1942^{\mathrm{a}}$ & $1876^{\mathrm{b}}$ & $1883^{\mathrm{b}}$ & $1892^{\mathrm{b}}$ & $1903^{b}$ & $1913^{b}$ \\
\hline
\end{tabular}

All values on the same row with the different superscripts are significantly difference $(\mathrm{P}<0.05)$.

$\mathrm{EM}=$ Earthworm meal

\section{Experimental set-up and feeding}

Five experimental sets in triplicate were used in this experiment. A total of 15 glass aquaria $(50 \mathrm{X} 40 \mathrm{X} 30 \mathrm{~cm})$, dechlorenated tab water was supplied to two-third of the size of the glass aquarium. All aquaria were covered with a net of mesh size $3 \mathrm{~mm}$ 
to protect the larvae of prawn from jumping out of the aquaria. A constant photoperiod of 12 light and $12 \mathrm{~h}$ dark was maintained.

A total number of 500 prawn larvae (Macrobrachium rosenbergii) of initial mean weight of $0.20 \pm 0.021 \mathrm{~g}$. and mean initial length of $2.8 \pm 0.321 \mathrm{~cm}$ were purchased from Hatchery of Mariout Fish Farming Company (MFFC), locating about $30 \mathrm{Km}$. west of Alexandria. Larvae were acclimatized for one week in circular plastic holding tanks $(0.75 \mathrm{~cm}$ in diameters) occupied with electric aerator and fed a diet having $35 \%$ crude protein in the laboratory.

Larvae of prawn were sorted, weighed, randomly stocked into the experimental aquaria at a rate of 20 larvae per aquarium. They were starved overnight before the commencement of the feeding trials. Larvae were offered the experimental diets at a rate of $3 \%$ of their body weight per day; administered in two equal portions between 8.00-9.00 and 18.00-19.00 h. The quantity of feed was adjusted based on the weight of prawn for previous week throughout the 10 weeks duration of the feeding trails. The prawns were monitored daily. Dead prawn and faeces and remains of food were removed, counting of prawn recorded and not replaced to calculate the survival rate.

\section{Prawns measurements}

The length and weight of each larva in each aquarium were measured at the commencement of the experiment. Subsequently, a sample of 5 prawns was taken randomly from each aquarium once every two weeks and weighed with electronic digital balance (Model MR-220) to access the growth rates. Feed offered were recorded daily and the following calculations were performed:

Specific growth rate (SGR)

SGR (\%/day) $=100\{\operatorname{Ln}(w f)-\operatorname{Ln}($ wi $)\} / T$

Where: $\mathrm{Wf}=$ Final weight $(\mathrm{g})$

$\mathrm{Wi}=$ Initial weight $(\mathrm{g})$

$\mathrm{T}=$ Number of experimental days

Weight gain (WG) was calculated as:

$\mathrm{WG}(\mathrm{g} /$ day $)=(\mathrm{Wf}-\mathrm{Wi})$

Feed conversion ratio (FCR) was calculated as:

$\mathrm{FCR}=$ Feed offered /weight gain of prawn

At the end of experiment, all prawns in each aquarium were counted. Survival rate was determined from the number left at the end of the experiment relative to the number stocked.

\section{Biochemical composition and statistical analysis}

Water temperature was measured daily with graduated thermometers, while dissolved oxygen and $\mathrm{pH}$ were measured weekly using Boyd (1990) method and digital pH meter (ML 1010), respectively.

Proximate composition of processed earth worm meal and fish meal, experimental diets, prawn carcasses before and after the experiments were analyzed for crude protein, crude lipid, ash, and nitrogen free extracts according to Association Official Analytical Chemist Methods (AOAC 2000). The mineral in the ash of each diet was brought into solution by wet digestion using conc. HNO3 (63\%), perchloric acid $(60 \%)$ and sulphoric acid $(98 \%)$ in the ratio of $4: 1: 1$ (Harris 1974). Potassium and Sodium were determined using flame photometer (Allen 1974).

The collected data were subjected to analysis of variance (ANOVA). Comparison among the means of treatments were carried out by one way analysis of variance followed by Tukey,s test (0.05). Least Significant Differences (LSD) was used to determine the level of significance among treatments at $\mathrm{P}=0.05$. 


\section{RESULTS AND DISCUSSION}

The crude protein content of fish meal and earthworm were significantly different $(\mathrm{P}<0.05)$ while that of the feed were not $(\mathrm{P}<0.05)$ (Table 2). The highest crude lipid, $(11.2 \%)$ was in $100 \%$ earthworm meal diet, while the lowest crude lipid $(5.92 \%)$ was in earth worm meal. The gross energy values of fish meal and earth worm were significantly higher $(\mathrm{P}<0.05)$ than that of each experimental diet (Table 2).

Various water quality parameters; water temperature, $\mathrm{pH}$ and dissolved oxygen (DO) were observed to be least affected by different treatment diets. The values of all the parameters, including water temperature, $\mathrm{pH}$ and $\mathrm{DO}$ were almost similar for all the treatment diets during the experimental period and was well within the optimal range proposed for the freshwater prawn by Boyd and Zimmerman (2000), Strauss et al. (1991) and Zimmerman (1998), respectively (Table 3).

Table 3: Average Water quality variables (mean $\pm \mathrm{SD}$ ) in the experimental aquaria of $M$. rosenbergii larvae fed with different diets for 60 days (average measures before water exchange every other day)

\begin{tabular}{llllll}
\hline & \multicolumn{5}{c}{ Experimental diets } \\
\hline \multicolumn{1}{c}{ Water quality variables } & \multicolumn{1}{c}{ EM1(control) } & \multicolumn{1}{c}{ EM2 } & \multicolumn{1}{c}{ EM3 } & \multicolumn{1}{c}{ EM4 } & EM5 \\
\hline Temperature ${ }^{\circ} \mathrm{C}$ & $30.2 \pm 0.755$ & $30.3 \pm 0.610$ & $30.3 \pm 0.750$ & $30.5 \pm 0.500$ & $30.6 \pm 0.693$ \\
$\mathrm{pH}$ & $7.4 \pm 0.100$ & $7.4 \pm 0.100$ & $7.5 \pm 0.200$ & $7.5 \pm 0.173$ & $7.6 \pm 0.100$ \\
Dissolved oxygen $\left(\mathrm{mgL}^{-1}\right)$ & $4.75 \pm 0.250$ & $4.80 \pm 0.265$ & $4.85 \pm 0.289$ & $4.77 \pm 0.321$ & $4.85 \pm 0.332$ \\
Total ammonia $\left(\mathrm{mgL}^{-1}\right)$ & $1.55 \pm 0.184$ & $1.45 \pm 0.091$ & $1.100 \pm 0.173$ & $1.5 \pm 0.127$ & $1.00 \pm 0.190$ \\
Total nitrite $\left(\mathrm{mgL}^{-1}\right)$ & $0.31 \pm 0.038$ & $0.33 \pm 0.092$ & $0.31 \pm 0.067$ & $0.11 \pm 0.036$ & $0.10 \pm 0.021$ \\
Alkalinity $\left(\mathrm{mgL}^{-1}\right.$ as $\left.\mathrm{CaCO}_{3}\right)$ & $105.0 \pm 8.660$ & $109.0 \pm 5.292$ & $109.0 \pm 10.149$ & $110.0 \pm 6.245$ & $113.0 \pm 10.263$ \\
\hline
\end{tabular}

\section{Growth}

The current study clearly demonstrated that feeding of $M$. rosenbergii larvae with earthworm meal at an appropriate period led to significantly improved growth performance and survival of the prawn larvae. The fact that biweekly weight increase was recorded in all treatments showed that non of the experimental diets contain antigrowth factors (Sogbesan et al. $2006 \mathrm{c}$ ). In the present study, the inclusion levels of dry earth worm meal appeared to be an important factor in influencing growth, acceptability index, feed utilization and diestability of prawn larvae. This observation was corroborate with that of Stafford and Tacon (1985) that weight gain reduced as earthworm inclusions level increased in practical diets of rainbrow trout. Similar reports were made by Guerrero (1983), Guerrero et al. (1984), Alegbeleye and Oresegun (1998) and Sayed (1998) who recorded adverse effect on the productivity of tilapia when fed earthworm supplemented diets.

The results of the growth performance of $M$. rosenbergii larvae exposed to different diets (Tables 4, 5\&6) clearly specified that the maximum final length, final weight and weight gain were observed in prawns exposed to diet having $25 \%$ earthworm meal(EM2). While the minimum length and weight gain was observed in prawn exposed to diet EM1 (control diet), the final average weight gain for different diets was in order: EM2>EM3 $>$ EM4 $>$ EM5 $>$ EM1 (Tables 4\&5). 
Table 4: Body length increments of $M$. rosenbergii larvae fed with different experimental diets for 60 days

\begin{tabular}{lcll}
\hline \multicolumn{2}{l}{ Body length of $M$. rosenbergii (Mean \pm SD) } & \\
\hline Diets & Initial length $(\mathrm{cm})$ & Final length $(\mathrm{cm})$ & Gained length $(\mathrm{cm})$ \\
\hline EM1 (Control) & $2.8 \pm 0.321$ & $4.2 \pm 0.153^{\mathrm{b}}$ & $1.4 \pm 0.153^{\mathrm{b}}$ \\
EM2 (25\% earthworm) & $2.8 \pm 0.321$ & $5.1 \pm 0.21^{\mathrm{a}}$ & $2.3 \pm 0.252^{\mathrm{a}}$ \\
EM3(50\%, earthworm) & $2.8 \pm 0.321$ & $4.4 \pm 0.208^{\mathrm{b}}$ & $1.6 \pm 0.306^{\mathrm{b}}$ \\
EM4 (75\% earthworm) & $2.8 \pm 0.321$ & $4.3 \pm 0.404^{\mathrm{b}}$ & $1.5 \pm 0.253^{\mathrm{b}}$ \\
EM5(100\% earthworm) & $2.8 \pm 0.321$ & $4.3 \pm 0.153^{\mathrm{b}}$ & $1.5 \pm 0.351^{\mathrm{b}}$
\end{tabular}

Values in the same column followed by different letters are significantly different $(\mathrm{P}<0.05)$

Values are Mean \pm SD.

Control $=$ free earthworm

Table 5: Weight increments of $M$. rosenbergii larvae fed with different experimental diets for 60 days

\begin{tabular}{llll}
\hline & Weight of $M$. rosenbergii $($ Mean \pm SD) & \\
\hline Diets & Initial weight $(g)$ & Final weight $(g)$ & Gained weight $(g)$ \\
\hline EM1 (Control, ) & $0.20 \pm 0.021$ & $0.61 \pm 0.020^{\mathrm{b}}$ & $0.41 \pm 0.038^{\mathrm{b}}$ \\
EM2 (25\% earthworm) & $0.20 \pm 0.021$ & $0.88 \pm 0.025^{\mathrm{a}}$ & $0.68 \pm 0.040^{\mathrm{a}}$ \\
EM3(50\%, earthworm) & $0.20 \pm 0.021$ & $0.69 \pm 0.026^{\mathrm{b}}$ & $0.49 \pm 0.031^{\mathrm{b}}$ \\
EM4 (75\% earthworm) & $0.20 \pm 0.021$ & $0.66 \pm 0.021^{\mathrm{b}}$ & $0.46 \pm 0.049^{\mathrm{b}}$ \\
EM5(100\% earthworm) & $0.20 \pm 0.021$ & $0.65 \pm 0.04^{\mathrm{b}}$ & $0.45 \pm 0.065^{\mathrm{b}}$ \\
\hline
\end{tabular}

Values in the same column followed by different letters are significantly different $(\mathrm{P}<0.05)$

Values are Mean \pm SD.

The average specific growth rate (SGR) for the different diets ranged between 1.5for prawns fed on EM1 and 2.98 for those exposed to EM2. The lowest and the best feed conversion ratio (FCR) was obtained for diet (EM2) which differ significantly $(\mathrm{P}<0.05)$ from other experimental diets (Table 6). From the values of FCR and SGR, it can be proposed that diet 2(EM2) which contain $25 \%$ earthworm was the best among all the dietary treatments and this may be due to the good nutrients and digestibility. This view is supported by Hardy (1996), Jain and Srivastava,(2000) and Francis et al. (2001). Also, Sogbesan et al. (2007) reported that the highest SGR, weight gain, protein efficiency ratio, and lowest feed conversion rate were recorded from $25 \%$ earthworm diet for Heterobranchus longifilis fingerlings. In this respect, Ramesh et al. (2001) and Sastry and Huria (2004) found that a complete replacement of fish meal with earthworm meal gave better growth values and survival in Catla catla fry. All diets realized bets survival rates, but prawn fed on EM2 and EM3 showed a higher survival rates represented by 93.5 and 93.1, respectively (Table 6). These results are in agreement with that obtained by Langer et al. (2011) who recorded that a significantly higher rate of growth, survival and FCR were recorded for prawns fed earthworm diet.

Table 6: Specific growth rates, food conversion ratios and survival rates of $M$. rosenbergii larvae fed with different experimental diets for 60 days.

\begin{tabular}{llll}
\hline Diets & Specific growth rate (\%) & Food conversion ratio & Survival rate (\%) \\
\hline EM1 (Control, ) & $1.5 \pm 0.200^{\mathrm{b}}$ & $1.6 \pm 0.100^{\mathrm{a}}$ & $82 \pm 2.23^{\mathrm{b}}$ \\
EM2 (25\% earthworm) & $1.98 \pm 0.388^{\mathrm{a}}$ & $1.1 \pm 0.218^{\mathrm{b}}$ & $93.5 \pm 3.62^{\mathrm{a}}$ \\
EM3(50\%, earthworm) & $1.65 \pm 0.332^{\mathrm{b}}$ & $1.4 \pm 0.173^{\mathrm{a}}$ & $93.1 \pm 4.29^{\mathrm{a}}$ \\
EM4 (75\% earthworm) & $1.59 \pm 0.189^{\mathrm{b}}$ & $1.5 \pm 0.173^{\mathrm{a}}$ & $85 \pm 3.315^{\mathrm{b}}$ \\
EM5(100\% earthworm) & $1.57 \pm 0.149^{\mathrm{b}}$ & $1.5 \pm 0.265^{\mathrm{a}}$ & $89 \pm 4.000^{\mathrm{ab}}$ \\
\hline
\end{tabular}

Values in the same column followed by different letters are significantly different $(\mathrm{P}<0.05)$

Values are Mean \pm SD.

In comparison with other worms such as silkworm pupae meal (SWP), earlier studies based on replacement of fish meal (FM) with SWP in common carp 
(Nandeesha et al. 1990), Catla and rohu (Jayaram et al. 1980) have shown the best growth of carps at 30\% pupae inclusion. However, Begum et al. (1994) recorded significantly better SGR, FCR and protein efficiency ratio for rohu fed with a diet having $50 \%$ of its protein contributed by SWP when compared to FM based diet. Our finding also confirm the study conducted by Langer et al. (2011) who found that a replacement of fish meal with silkworm pupae yielded better growth results in terms of weight gain, SGR, FCR and survival rate of the freshwater prawn, M. dayanum. The present study revealed that as earthworm meal increased in the diet growth performance decreased and this was in agreement with that obtained by Alegbeleye and Oresegon (1998) who linked the poor growth and nutrient utilization of Oreochromis niloticus fed complete earthworm meal to unpalatable tendency of the worms due to secretion of elaocyte cells in its epithelium. Despite this, Cardinete et al. (1991) had also reported reduction in food intake and nutritive utilization of protein in rainbow trout fingerlings fed earthworm meal diet and linked this to the presence of ceolmic fluid in the earthworm hence fish will definitely perform better at low earthworm meal inclusions in their diet.

The biochemical composition of the flesh of prawn fed the five experimental diets was estimated in terms of moisture, total protein, total lipids and ash on the dry matter (DM) basis (Table 7). The moisture content of the prawn before culture was estimated to be $80.7 \%$ and decreased after the experimental period (at the end of experiment) but not significantly differed $(\mathrm{P}>0.05)$ and represented by 79.9, 79.3, $80.3,80.1$ and $79.85 \%$ in diet EM1, EM2, EM3, EM4 and EM5, respectively. The crude protein content (on DM basis) before culture was $59.6 \%$. After culture, its value was analyzed as 60.1 for diet EM1, 62.9 in diet EM2, 59.1 in diet EM3, 59.8 in diet EM4 and 60.1 in diet EM5.The value of protein for all treatments did not differ significantly $(\mathrm{P}>0.05)$.

Table 7: Biochemical composition of the flesh of $M$. rosenbergii before and after culture

\begin{tabular}{lllllll}
\hline \multirow{2}{*}{ Parameters } & After culture & \multicolumn{5}{l}{} \\
\cline { 3 - 7 } & Before culture & EM1 & EM2 & EM3 & EM4 & EM5 \\
\cline { 3 - 7 } Moisture (\%) & $80.7 \pm 0.700$ & $79.9 \pm 12.29$ & $79.3 \pm 3.47$ & $80.3 \pm 4.18$ & $80.1 \pm 8$ & $79.85 \pm 3.276$ \\
Total Protein (\%) & $59.6 \pm 1.528$ & $60.1 \pm 1.23$ & $62.9 \pm 1.358$ & $59.1 \pm 1.68$ & $59.8 \pm 0.79$ & $60.1 \pm 0.656$ \\
Total Lipid (\%) & $7.97 \pm 0.153$ & $7.8 \pm 0.265$ & $7.3 \pm 0.200$ & $6.95 \pm 0.18$ & $7.2 \pm 0.100$ & $7.2 \pm 0.173$ \\
Ash (\%) & $20.1 \pm 0.985$ & $20.3 \pm 0.613$ & $19.8 \pm 0.251$ & $19.6 \pm 0.781$ & $19.8 \pm 1.40$ & $19.5 \pm 2.066$
\end{tabular}

Values are Mean \pm SD.

From this study Diet 2 (EM2) showed the highest value of crude protein $(62.9 \%)$ of prawns. The non significant difference in protein content of prawns fed different diets could have been due to isonitrogenous profile of these diets despite having variable protein sources. Ali and Sahu (2002) found similar observation in $M$. rosenbergii juveniles wherein three isocaloric and isonitrogenous diets having different protein sources did not affect the carcass crude protein. Ash content also showed insignificant differences $(\mathrm{P}>0.05)$, however, Diet $1(\mathrm{EM} 1)$ gave the highest value of ash $(20.3 \%)$ than the other experimental diets. Diet EM1 gave the highest value of the total lipid content compared to the other four diets, while the lowest one was recorded with prawn exposed to EM3. However, differences in total lipid contents among all diets used was insignificant $(\mathrm{P}>0.05)$ between. In this respect, Sogbesan et al. (2007) demonstrated that fish, Heterobranchus longifilis fingerlings showed increasing in the apparent net lipid utilization along with earthworm meal inclusion could attribute higher inclusion of this animal protein supplement with increase in fat deposition in fish muscle which could lead to production of fatty fish. 
In conclusion earthworms have a high nutritive value as a cheaper protein ingredient and can used as a replacement of fish meal in the diets of $M$. rosenbergii. This study, therefore clearly revealed better growth, SGR, FCR and survival for $M$. rosenbergii fed dry earthworm meal at inclusion of $25 \%$ and this may lower the cost of diet production.

\section{REFERENCES}

Akpodiete, O.J. and Okagbere, G.N. (1999) .Feed Accessories from Animal Production. In: Issues on Animal Sciences. In: A compendium of Ideas, Fact and Method in the Science and Technology of Animal Agriculture, Omeje, S.I.(Ed). Ran Kennedy, New York, pp. 71-82.

Alegbeleye, W.O. and Oresegun, A. (1998). Nutritive value of Three Terrestrial Lumbird Worm for Oreochromis niloticus. In: Sustainable Utilization of Aquatic Wetlands Resources, Otubusin, S.O., G.N.O. Ezeni, A.O. Ugwumba and A. A. A. Ugwumba (Eds.), Aqua Society of Nigeria, Nigeria, pp. 165-175.

Ali, S. and Sahu, N.P. (2002). Response of Macrobrachium rosenbergii (de Man) juveniles to fish silage as substitute for fish meal in dry diets. Asian Fish Sci., 15(1): 59-60.

Allen, S.E. (1974). Chemical Analysis of Ecological Materials. $2^{\text {nd }}$ Edn., Blackwell Scientific Publisher Oxford, UK., pp. 213.

Annune P.A. (1990). Preliminary investigation on the suitability of Toad meal, Bufo regularis. (Ruess, 1834), in the diets of Clarias lazera curvier and valenciences. J. Aqua. Sci., 5: 37-42.

AOAC (2000). Official Methods of Analysis. 17 $7^{\text {th }}$ Edn., Association of Official Analytical Chemistry, Arlington, Virginia, USA.

Ayinla, O.A.; Kayode, O.; Idonibuoye-Obu T.I.E.; Oresegun A. and Adindu V.E.(1994). Use of Tadpole meal as substitute for fish meal in the diet of Heterobranchus bidorsalis (Geofrey st., Hillaire 1809). J. Aquac. Trop., 9: 25-33.

Begum, N.N.; Chakraborthy, S.C.; Zaher, M.; Abdul, M.M. and Gupta, M.V.(1994). Replacement of fish meal by low cost animal protein as a quality fish feed ingredients for the Indian major carp, Labeo rohita, fingerlings. J. Food Agric. Sci., 64: 191-197.

Boyd C.E. (1990). Water quality in ponds for aquaculture Alabama agriculture experiment station, Auburn University. Birmingham Publishing Co. Birmingham, Alabama. First printing 5M, December 1990.

Boyd, C. and Zimmerman, S. (2000). Grow out systems-water quality and soil management. In: Freshwater prawn culture (The farming of Macrobrachium rosenbergii, (Eds. New, M.B. and Valenti, W.C.0: pp. 221-238.

Cardinete, E.G.; Garzon, A.Moyano, F. and Dela Higuera, M. (1991). Nutritive utilization of earthworm protein by fingerling rainbow Trout(Oncorhychus mykiss). Fish Nutrition in Practice, Biarritz (France), pp. 923-926.

Fagbenro, O.A. and Jauncey, K.(1995). Water stability, nutrient leaching and nutritional properties of moist fermented fish silage diets. Aqua. Eng., 14:143-153.

Falayi B.A. (2003). Techniques in fish feed manufacture. Proceedings of the joint Fisheries Society of Nigeria Institute For Freshwater Fisheries Research/FAO-National Special Programme For Food Security National Workshop on Fish Feed Development and Feeding Practices in Aquaculture, Sept. 15-19, National Institute of Freshwater Fisheries Research, New Bussa, pp. 43-55.

FAO (2010). The State of World Fisheries and Aquacult. Part 1: World Review of fisheries and aquaculture, Overview, p.3 ftp://ftp.fao.org/docrep/fao/011/i025eo1.pdf

Fasakin, E.A.; Bello-Olusoji, O.A. and Oyekanmi, F.B. (2000). Nutritional value, flesh and waste composition of some processed commercially important crustaceans in Nigeria. Applied Tropical Africult., 5(2): 148-153. 
Francis, G.; Makkar, H.P.S. and Becker, K. (2001). Anti nutritional factors present in plantderived alternate fish feed ingredients and their effect in fish. Aquaculture, 199:197227.

Guerrero, R.D. (1983). The culture and use of Perionxy excavates as protein resource in the Philippines. In:Earthworm Ecology, Satchell, J.E. (Ed.), Chapman and Hall, London, $495 \mathrm{pp}$.

Guerrero, R.D.; Guerrero, L.A. And Cargado, A.U. (1984). Studies on the culture of the earthworm, Eudrilus eugdinae and its use as fed for Macrobrachium idella and fertilizer source for Brassica compensis. Trans. Nat. Acad. Sci. Technol., 6: 33-40.

Hardy, R.W. (1996). Alternative protein sources for salmon and trout diets. Animal. Feed Sci. Technol., 59: 71-80.

Harris, E. (1974). Nutrition research. Techniques for domestic and wild animals. Utah, USA., $147 \mathrm{pp}$.

Jain, K.K. and Srivastava, P.P. (2000). Acceptability of low cost feed ingredients in pelleted feed for freshwater giant prawn, Macrobrachium rosenbergii. National Workshop on Aquaculture of Freshwater prawns, 8-9 Feb., 2000. Abstract no. 60.

Jayaram, M.G.; Shetty H.P.C. and Udupa, K. S. (1980). Organoleptic evaluation of flesh of carps fed on different kinds of feeds. Mysore J. Agric. Sci., 14: 421-424.

Karimi, A. (2006). The effect of varying fish meal inclusion levels (\%) on performance of broiler chicks. Int. J. Poult. Sci., 5: 255-258.

Langer, S.; Bakhtiyar, Y. and Lakhnotra, R. (2011). Replacement of fishmeal with locally available ingredients in diet composition of Macrbrachium dayanum. African J. of Agricultural Research, 6(5): 1080-1084.

Latsamy P. and Perston T.R. (2007) .Fly larvae, earthworms and duckweed as feeds for frogs in an integrated farming system. MSc Thesis, MEKARN-SLU http://www.mekarn.org/MSC2005-07/thesis07/lasts2.htm

Loan,P.P.; Nhi, H.Y.; Van, T.T. and Phu, T.P.(2009). Earthworm (Perionyx excavatus) as a main protein source for growing zig-zag eel (Mastacembelus armatus) in small household aquaculture-based farming system in the Mekong river delta. International Workshop. Livestock, climate change and the environment. Htt:/www.mekarn.org/workshops/environ/PDF/loan.pdf

Nandeesha, M.C.; Sricanth, G.K.; Keshavappa, P.Vargheses, T.J. ;Basavaraja, N. and Das, S.K. (1990). Effects of non-defatted silkworm pupae in diets on growth of common carp, Cyprinus carpio. Biol. Wastes, 33:17-23.

Ramesh , P.T.; Gunathilagarai, K.; Nagamani, B. and Ganeshkumar, M.(2001). Effect of earthworm meal on the growth of common carp, Cyprinus carpio L. Asian J. Microbiol. Biotech. Env. Sci., 3(4): 293-295.

Rangachacharyulu, P.V. (1999). Studies on the nutrition and diet development of the giant freshwater prawn, Macrobrachium rosenbergii Ph.D Thesis, University of Kalyani, West Bengal, India.

Sastry, K.V. and Huria, M. (2004) Supplementation of earthworm meal in the diet of Catla catla fry. Aquaculture, 5(1): 177-181.

Sayed, A.N. (1998). Evaluation of poultry by-product and earthworm meals as protein sources for Tilapia fish. Assiut. Vet. Med. J.,40:133-149.

Sogbesan, O.A.; Ajuonu, N.D.; Ugwumba, A.A.A. and Madu, C.T.(2005). Cost benefits and growth performances of catfish hybrid fed maggot meal diets. J. Sci. Ind. Res., 3: 5156.

Sogbesan, O.A.; Ugwumba, A.A.A. and Madu, C.T. (2006 a). Nutritive potentials and utilization of Garden snail (Limicolaria aurora, Jay, 1937; Gastropoda: Limicolaria) meat meal in the diet in the diet of Clarias gariepinus fingerlings (Burchell, 1822). Afr. J. Biotechnol., 5: 1999-2003.

Sogbesan, O.A.; Ugwumba, A.A.A. and Ibiwoye, T.I.I. (2006 b). Growth performance and nutritional of semi-arid zone earthworm (Hyperiodrilus euryaulos; Clausen, 1967) cultured in some organic wastes as fish meal supplement. Nig. J. Trop. Agric., 8:255262. 
Sogbesan, O.A.; Ajuonu, D.N.; Musa, B.O. and Adewole, A.M. (2006 c). Harvesting techniques and evaluation of maggot meal as dietary animal protein source for Heteroclarias fingerlings outdoor concrete tanks. World J. Agric. Sci., 2: 394-402.

Sogbesan, O. A.; Ugwumba, A.A.A.; Madu, C.T.; Eze, S.S. and Isa, J.(2007). Culture and utilization of earthworm as animal protein supplement in the diet of Heterobranchus longifilis fingerlings. J. Fish. Aquat. Sci., 2: 375-386.

Spotts, D. (1981). Introducing Macrobrachium rosenbergii. FreshWater Marine Aquarium, $4(7): 32-34$.

Stafford, E.A. and Tacon, A.G.J. (1985). The nutritional evaluation of dried earthworm meal included at low levels in production diets for rainbrow trout, Salmo gairdneri, Richardson. Aquacult. Fish. Manage., 16: 213-222.

Strauss, D.L.; Robinette, H.R. and Heinen, J.M. (1991). Toxicity of un-iodized ammonia and $\mathrm{pH}$ to post-larval and juvenile freshwater shrimp Macrobrachium rosenbergii. J. World Aquacult. Soc., 22: 128-133.

Ugwumba, A.A.A.; Ugwumba , A.O. and Okunola, A.O. (2001). Utilization of live maggot as supplementary feed on the growth of Clarias gariepinus (Burchell) fingerlings. Nig. J. Sci., 35: 1-7.

Vu Dinh Ton, V.D.; Hanh, H.Q.; Linh, N.D. and Duy, N.V.(2009). Use of red worms (Perionyx excavatus) to manage agricultural wastes and supply valuable feed for poultry. http://www.Irrd21/11/ton21192.htm

Yaqub, H. B. (1997). Earth worm and maggot meals as a potential fish meal replacement. http://www.oceandocs.org/bitstream/1834/1268/1/paper1feed.pdf

Zimmerman, S. (1998). Management of final growth phase. In: shrimp farming of freshwater :technology for production of Cayman, (ed.by W.C. Valenti), Fundacao de Amparo a Pesquisa do Estado de Sao Paulo (FAPESP) and the Brazilian Institute of Environment and natural resources (Ibama) Brasilia Energies, pp. 192-215.

\section{ARABIC SUMMARY}

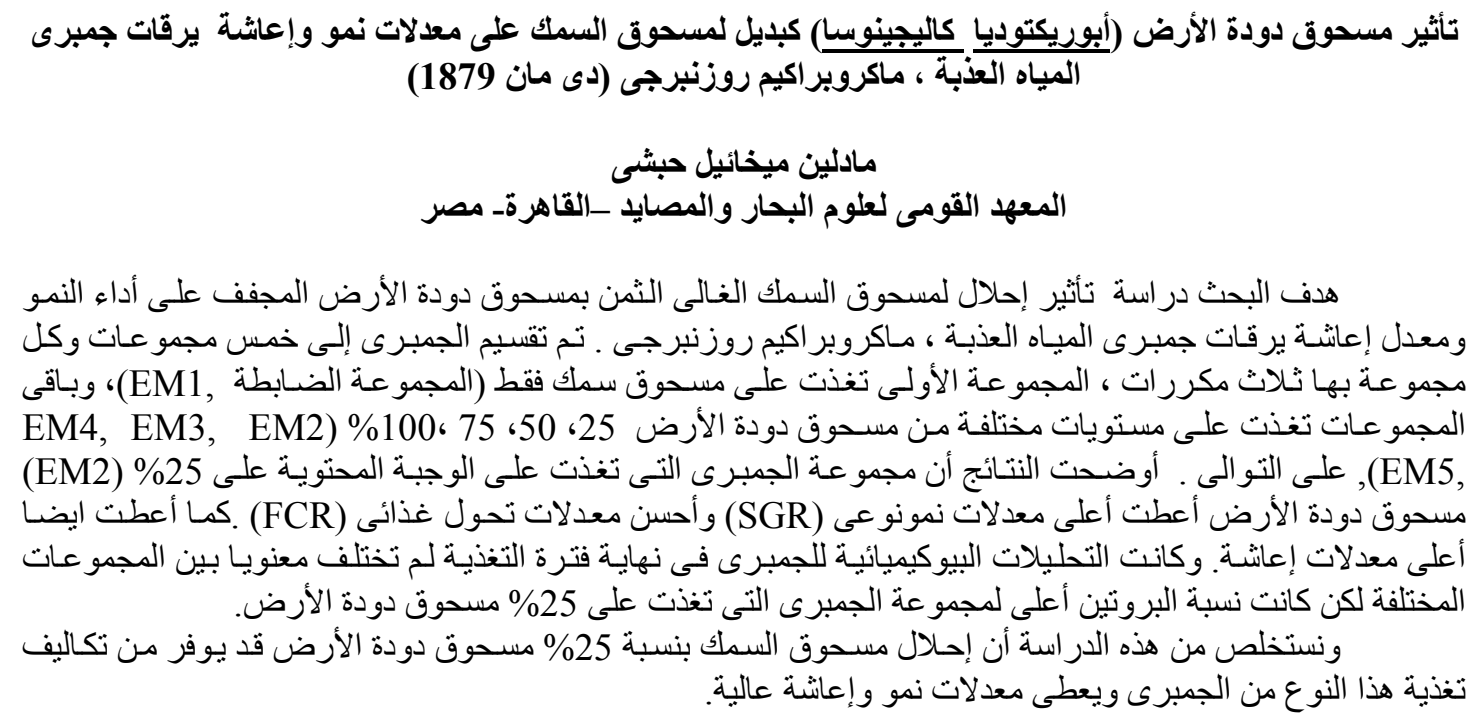

